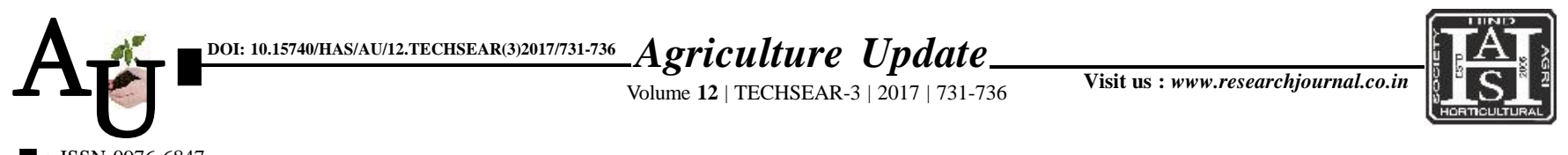

—e ISSN-0976-6847

\title{
Research Article: Effect of plant spacing on different genotype of pigeonpea [Cajanus cajan(L.) Millisp]
}

\author{
U.N. ALSE, S.K. NAYAK, S.G. JADHAV AND S.U. VIDHATE
}

Article Chronicle:

Received :

10.07.2017;

Accepted :

25.07.2017

KeY Words:

Genotype, Spacing,

Pigeonpea, Yield
SUMMARY : A field investigation entitled "Effect of plant spacing on different genotype of pigeonpea [Cajanus cajan (L.) Millisp] was conducted during Kharif 2013-14 at experimental farm Department of Agronomy, College of Agriculture, Vasantrao Naik Marathwada KrishiVidyapeeth, Parbhani, to study effect of spacing on the growth and yield of pigeonpea, to evaluate performance of genotype of pigeonpea on different spacings. The experiment was conducted in split plot design with four spacings i.e. $\mathrm{S}_{1}-60 \times 30 \mathrm{~cm}, \mathrm{~S}_{2}-90 \times 20 \mathrm{~cm}, \mathrm{~S}_{3}-120 \times 15 \mathrm{~cm}$, and $\mathrm{S}_{4}-60 \times 60-120 \mathrm{~cm}$ in main plot and three genotypes $\mathrm{G}_{1}$-BSMR-853, $\mathrm{G}_{2}$-MUTANT(M)-853 and $\mathrm{G}_{3}$-BDN-711 in sub plots with twelve treatment combinations. It can be concluded that, the spacing of $120 \times 15 \mathrm{~cm}\left(2341 \mathrm{~kg} \mathrm{ha}^{-1}\right)$ and $60 \times 60-120 \mathrm{~cm}$ $\left(2237 \mathrm{~kg} \mathrm{ha}^{-1}\right)$ were found highly productive as compared to $90 \times 20 \mathrm{~cm}, 60 \times 30 \mathrm{~cm}$. Among the genotypes of pigeonpea BDN-711 (2119 kg ha-1), found significantly higher over BSMR-853, however it was at par with MUTANT (M)-853 (2000 $\left.\mathrm{kg} \mathrm{ha}^{-1}\right)$.

How to cite this article : Alse, U.N., Nayak, S.K., Jadhav, S.G. and Vidhate, S.U. (2017). Effect of plant spacing on different genotype of pigeonpea [Cajanus cajan (L.) Millisp]. Agric. Update, 12(TECHSEAR-3) : 731-736; DOI: 10.15740/HAS/AU/12.TECHSEAR(3)2017/731-736. 